\title{
The Miracle of Mangrove, Peningkatan Pengetahuan dan Kesadaran Masyarakat Kuri Caddi terhadap Keberadaan Mangrove
}

\section{(The Miracle of Mangrove, Increasing the Knowledge and Awareness of the Existence of Mangrove in Kuri Caddi Community)}

\author{
Andi Hurul Auni Usman ${ }^{1 *}$, Meta Dilianti Palimbunga ${ }^{1}$, Basran Nur Basir ${ }^{1}$, Aswar ${ }^{1}$, Ma'rifa Baharuddin ${ }^{2}$, \\ Ira Taskirawati ${ }^{1}$ \\ 1 Program Studi Kehutanan, Fakultas Kehutanan, Universitas Hasanuddin, Jl. Perintis Kemerdekaan KM.10, \\ Tamalanrea Indah, Tamalanrea, Kota Makassar, Sulawesi Selatan 90245. \\ 2 Program Studi Manajemen Sumberdaya Perairan, Fakultas Ilmu Kelautan dan Perikanan, Universitas Hasanuddin, \\ Jl. Perintis Kemerdekaan KM.10, Tamalanrea Indah, Tamalanrea, Kota Makassar, Sulawesi Selatan 90245. \\ *Penulis Korespondensi: andihurulauniusman@gmail.com \\ Diterima Juni 2019/Disetujui Desember 2019
}

\begin{abstract}
ABSTRAK
Potensi sumber daya alam hutan mangrove dan ekosistem laut di Dusun Kuri Caddi mendorong tim Program Kreativitas Mahasiswa (PKM) mahasiswa Universitas Hasanuddin dalam kegiatan PKM-M Blue-Forest untuk mengajak masyarakat melaksanakan kegiatan pengabdian. Tujuan kegiatan ini adalah untuk meningkatkan pengetahuan dan kesadaran masyarakat terhadap keberadaan mangrove di Dusun Kuri Caddi. Sebelum kegiatan, terlebih dahulu dilakukan pre-test untuk mengetahui kemampuan awal masyarakat mengenai mangrove. Proses pelaksanaan kegiatan menggunakan metode ceramah, diskusi, praktik langsung, dan brainstorming. Pada tahap evaluasi digunakan post-test untuk mengindentifikasi kemajuan pemahaman belajar masyarakat. Setelah kegiatan Blue-Forest, masyarakat telah mengalami peningkatan pengetahuan mengenai materi pengenalan mangrove sebesar $61 \%$ dari $100 \%$, kesadaran pemanfaatan sebesar $63 \%$ dari $100 \%$, dan bagian-bagian mangrove 63\% dari 100\%. Sebelum kegiatan PKM-M Blue-Forest dilaksanakan pengetahuan ratarata mitra mengenai mangrove hanya $26 \%$ dari $100 \%$. Setelah kegiatan ini dilaksanakan, pengetahuan mitra meningkat menjadi $61 \%$ dari $100 \%$.
\end{abstract}

Kata kunci: Kuri Caddi, mangrove, pemanfaatan, pengetahuan

\begin{abstract}
The potential natural resources namely mangrove forests and marine ecosystems in the Kuri Hamlet The Caddi Team encouraged the Student Creativity Program (PKM) of Hasanuddin University students in the PKM$M$ Blue Forest activities to encourage the community to carry out community service activities. The purpose of this activity is to increase public knowledge and awareness about mangrove challenges in the Kuri Caddi Hamlet. Prior to the activity, prior tests were conducted to measure the community's initial ability regarding mangroves. The implementation process teaches how to use lecture, discussion, direct practice, and brainstorming methods. Then to use the evaluation used a post-test to identify increased understanding of community learning. After the Blue-Forest Activity, the community increased their knowledge about mangrove introduction material by $59 \%$ from $100 \%$, Awareness of utilization by $63 \%$ from $100 \%$ and mangrove forest parts by $63 \%$ from $100 \%$. Prior to the activity, PKM-M Blue-Forest carried out based on average knowledge about mangroves was only $26 \%$ from $100 \%$. After this activity is carried out, the partner's knowledge increases to $61 \%$ from $100 \%$.
\end{abstract}

Keywords: advantage, knowledge, Kuri Caddi, mangrove

\section{PENDAHULUAN}

Indonesia merupakan negara yang memiliki banyak tempat indah dan menawan yang dapat dijadikan sebagai destinasi wisata. Kartawinata \& Soemodihardjo (1977) menuliskan bahwa wilayah pesisir dan lautan Indonesia terkenal dengan kekayaan dan keanekaragaman sumber daya alamnya, baik sumber daya yang dapat pulih (perikanan, hutan mangrove, dan terumbu karang (coral reefs), padang lamun, dan lain-lain), maupun sumber daya yang tidak dapat pulih (minyak bumi dan gas, serta mineral atau bahan tambang lainnya).

Salah satu tempat yang memiliki kekayaan keanekaragaman mangrove dan ekosistem laut yang indah berada di Sulawesi Selatan tepatnya 
di Dusun Kuri Caddi. Dusun Kuri Caddi berada di Desa Nisombalia, Kecamatan Marusu, Kabupaten Maros, Sulawesi Selatan terletak di tepi pantai yang jauh dari pusat kota. Dusun Kuri Caddi dihuni oleh 200 orang kepala keluarga yang hampir $100 \%$ berprofesi sebagai nelayan kepiting rajungan. Potensi sumber daya alam di Dusun Kurri Caddi terdiri atas 23 macam jenis mangrove dan biota laut (seperti ikan, udang, dan kepiting). Secara ekologi, mangrove memiliki manfaat sebagai penyangga sedimentasi, tempat hidup biota laut, sumber kehidupan bagi manusia dan abrasi, serta pencegah intrusi air laut. Hutan mangrove dan ekosistem laut yang tidak dijaga kelestariannya akan mengalami kerusakan yang sangat berdampak negatif pada ekologi, ekonomi, dan sosial masyarakat. Dampak negatif yang sangat nyata yang di rasakan oleh masyarakat Kurri Caddi adalah berkurangnya hasil dari mata pencaharian (rusaknya habitat biota laut seperti ikan, udang, dan kepiting), dan naiknya garis pantai. Sehingga hutan mangrove yang dikenal dengan ekosistem terproduktif dari ekosistem daratan manapun karena memiliki banyak potensi sehingga sangat perlu untuk dijaga kelestariannya.

Masalah yang muncul adalah masyarakat Kuri Caddi belum mengenal dengan baik berbagai jenis spesies mangrove yang tumbuh di pantai Kuri Caddi, serta manfaat dan pentingnya keberadaan mangrove yang ada di Kurri Caddi. Pentingnya mangrove bagi kehidupan manusia mendorong tim Program Kreativitas Mahasiswa (PKM) mahasiswa Universitas Hasanuddin dalam kegiatan PKM-M Blue-Forest untuk mengajak masyarakat melaksanakan kegiatan pengabdian yaitu pembelajaran tentang the miracle of mangrove dengan tujuan meningkatkan pengetahuan dan kesadaran masyarakat terhadap keberadaan mangrove di Dusun Kuri Caddi.

\section{METODE PELAKSANAAN KEGIATAN}

Kegiatan pengabdian the miracle of mangrove dilaksanakan di Dusun Kuri Caddi terletak di Desa Nisombalia, Kecamatan Marusu, Kabupaten Maros, Sulawesi Selatan. Kegiatan ini berlangsung selama tiga bulan, dimulai dari bulan Maret 2019. Peserta kegiatan sebanyak 10 orang yang merupakan anggota dari Sekolah Lapang Kerja (SLK). SLK adalah lembaga yang bentuk oleh masyarakat Kurri Caddi dan bergerak dalam pemberdayaan mangrove.
Media pembelajaran yang digunakan dalam kegiatan ini adalah buku berjudul the miracle of mangrove yang diajarkan dengan metode ceramah, diskusi, praktik langsung, dan brainstorming. Pembelajaran juga dilaksanakan secara outdoor di hutan mangrove yang ada di Dusun Kuri Caddi dengan tujuan agar masyarakat dapat mengenal langsung mangrove yang ada di dusun tersebut. Buku the miracle of mangrove terdiri atas beberapa bagian secara urut meliputi; 1) Penjelasan umum mengenai mangrove; 2) Bagian-bagian dari pohon mangrove disertai dengan gambar dan bahasa Inggris; 3) Penjelasan mengenai manfaat mangrove sebagai tanaman budi daya wilayah pesisir; dan 4) Beberapa jenis pemanfaatan mangrove. Buku ini juga disertai dengan gambar untuk lebih memudahkan dalam pengenalan mangrove.

Data yang dikumpulkan merupakan data pengetahuan awal mitra dan data setelah kegiatan dilaksanakan yang diperoleh melalui pemberian pre-test dan post-test yang terdiri atas 10 nomor soal (multiple choice) dengan cakupan materi mengenai pengertian mangrove, jenisjenis mangrove, tipe-tipe bagian tubuh mangrove. Satu nomor diberi bobot 10. Berdasarkan perolehan data tersebut didapatkan hasil adanya peningkatan pengetahuan mengenai materi pengenalan mangrove dan bagian-bagian mangrove yang diukur dengan meningkatnya hasil yang diperoleh dari post-test. Data peningkatan kesadaran dalam pemanfaatan hutan mangrove diperoleh dari hasil diskusi dan wawancara dengan mitra kemudian diolah secara deskriptif. Pengetahuan awal masyarakat didapatkan dari pembagian kuesioner yang merupakan bentuk pre-test yang isinya berupa, pengetahuan mengenai hutan mangrove, jenis-jenis mangrove, macam-macam mangrove, bentuk buah dan daun mangrove, serta zona-zona mangrove. Materi tersebut merupakan materi dasar dalam pengenalan mangrove. Pembuatan kuesioner ini bertujuan untuk mengetahui pengetahuan awal masyarakat mengenai mangrove.

\section{HASIL DAN PEMBAHASAN}

Materi-materi yang terdapat dalam buku The Miracle of Mangrove dijadikan dasar untuk mengetahui peningkatan pengetahuan dan kesadaran mitra akan mangrove. Mitra telah mengikuti keseluruhan kegiatan yang telah diagendakan. Peningkatan pengetahuan masyarakat dapat diketahui melalui pengenalan 
mangrove, bagian-bagian dari pohon mangrove, dan pemanfaatan mangrove.

\section{Pengenalan Mangrove}

Pada kegiatan ini materi berisi mengenai definisi mangrove secara umum, jenis-jenis tanaman mangrove, dan zona pertumbuhan mangrove. Gambar 1 menunjukkan grafik capaian kegiatan sebelum dan setelah kegiatan dilaksanakan. Sebelum kegiatan dilaksanakan, dari 10 orang mitra hanya $28 \%$ mitra yang paham mengenai pengertian mangrove hal ini diketahui dengan hasil dari pre-test yang telah diberikan. Masyarakat mitra awalnya hanya mengetahui jika mangrove adalah kumpulan pohon-pohon yang ada dipinggir pantai. Setelah kegiatan dilaksanakan, terdapat 6 orang mitra (61\%) telah mengenal mangrove dapat seperti pada Gambar 1. Mitra tersebut telah menjawab hasil post-test dengan benar dan telah mengetahui tentang definisi mangrove secara umum, bagian-bagian mangrove dan jenis-jenis mangrove. Pengetahuan masyarakat mengenai mangrove masih rendah pada wilayah yang belum pernah dilaksanakan penyuluhan mengenai mangrove hal ini sangat berbeda dengan wilayah yang telah mendapat penyuluhan mengenai mangrove (Widiastuti et al. 2018). Hal tersebut sesuai dengan apa yang terjadi pada masyarakat Kurri Caddi, mereka belum pernah mendapatkan sosialisasi mengenai mangrove. Awalnya masyarakat hanya mengenal mangrove sebatas nama daerah saja, tanpa mengetahui hal seperti definisi mangrove secara umum, bagianbagian mangrove, dan jenis-jenis mangrove.

Terdapat lima jenis tanaman mangrove yang banyak tumbuh di Indonesia, antara lain Avicennia, Bruguiera, Ceriops, Rhizophora, dan Sonneratia. Sementara itu, pada awal pengajaran masyarakat mitra tidak mengenal jenis-jenis mangrove dalam bahasa latin, namun ada dua jenis yang dikenal dengan bahasa daerah mereka, yaitu api-api (Avicennia), dan pidada (Sonneratia). Begitu pula halnya dengan zona pertumbuhan mangrove, masyarakat mitra hanya paham jika tanaman mangrove tumbuh pada daerah basah dan berair. Menurut Djohan (2007) mangrove umumnya tumbuh dalam empat zona, yaitu mangrove terbuka, mangrove tengah, mangrove payau, dan mangrove dataran.

\section{Bagian-bagian Pohon Mangrove}

Pada bagian ini materi berisi mengenai bentuk akar, buah, dan daun dari tanaman mangrove. Gambar 2 menunjukkan grafik capaian kegiatan

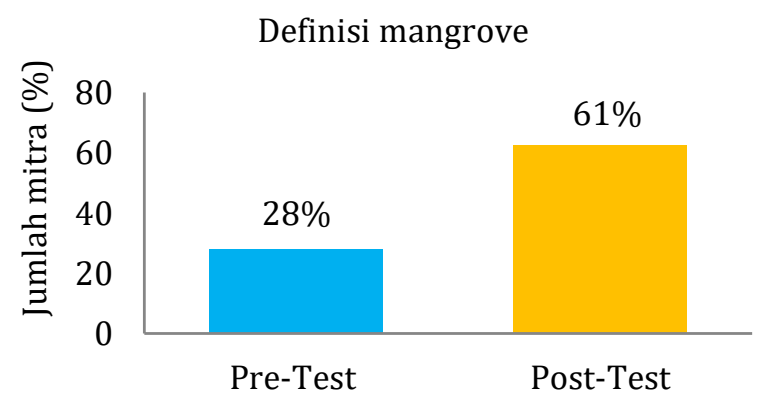

Gambar 1 Hasil pre-test dan post-test kegiatan pengenalan mangrove.

Bagian-bagian mangrove

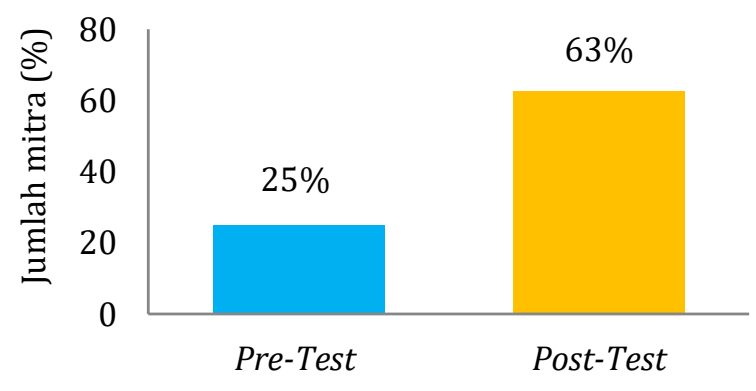

Gambar 2 Hasil pre-test dan post-test kegiatan bagianbagian dari tanaman mangrove.

sebelum dan sesudah dilaksanakan. Sebelum kegiatan dilaksanakan, dari 10 orang mitra hanya $25 \%$ mitra yang paham mengenai bentuk akar, buah dan daun dari tanaman mangrove. Setelah kegiatan dilaksanakan, dari 10 orang mitra terdapat $63 \%$ mitra telah mengenal bagianbagian dari tanaman mangrove. Masyarakat mitra awalnya tidak mengenal sama sekali jenisjenis perakaran mangrove hal ini terjadi karena kurangnya kesadaran mitra akan pentingnya mangrove dan tidak pernah dilakukan penyuluhan secara intesif terkait mengenai mangrove diwilayah tersebut. Menurut Halidah (2014) terdapat lima jenis perakaran mangrove, yaitu akar tunjang, pensil, udara, banir, dan akar lutut.

Pada awal pengajaran, masyarakat mitra hanya mengetahui satu jenis bentuk buah mangrove, yaitu memanjang karena minimnya pengetahuan mereka terhadap bentuk buah mangrove. Macam-macam tipe akar seperti akar tunjang, akar pensil, akar papan, dan akar lutut merupakan bentuk spesialisasi morfologi yang cukup valid sebagai penanda takson tertentu pada mangrove. Demikian pula morfologi buah yang membentuk berbagai variasi propagul dapat digunakan sebagai karakter yang berharga untuk membedakan kelompok pada mangrove (Tomlinson 1986). Sama halnya dengan bentuk 
daun mangrove, pada awal pengajaran masyarakat mitra hanya mengetahui satu jenis bentuk daun, yaitu elliptic. Hal ini sesuai dengan pendapat Suryadiputra (2006) yang memaparkan bahwa terdapat beberapa bentuk daun mangrove, beberapa di antaranya elliptic, lanceolate, dan spathulate. Hasil post-test menunjukkan bahwa pengetahuan masyarakat telah bertambah. Setelah kegiatan berakhir telah ditunjuk tiga orang kader dengan nilai post-test tertinggi sehingga mampu melanjutkan kegiatan ini.

\section{Pemanfaatan Mangrove}

Pada bagian ini, materi berisi berbagai jenis pemanfaatan mangrove. Gambar 3 menunjukkan grafik capaian kegiatan sebelum dan setelah kegiatan dilaksanakan. Sebelum kegiatan dilaksanakan, dari 10 orang mitra hanya $25 \%$ mitra yang paham manfaat keberadaan mangrove. Setelah kegiatan dilaksanakan, dari 10 orang mitra terdapat $63 \%$ mitra telah paham manfaat keberadaan mangrove (Gambar 3). Artinya pengetahuan mitra bertambah dan mampu menjadi masyarakat kader untuk kegiatan ini. Selama ini, masyarakat hanya mengenal mangrove sebagai tanaman obat karena kurangnya pengetahuan mengenai manfaat-manfaat penting mangrove. Menurut Kordi (2012), mangrove memiliki sepuluh manfaat, yaitu memberi nutrisi, sebagai rantai makanan, penjaga kualitas air dan udara, mencegah erosi pantai, memberikan dampak ekonomi yang luas, sumber pakan ternak, mencegah pemanasan global, sumber pendapatan bagi nelayan pantai, pengembangan kawasan pariwisata, menyediakan sumber kayu bakar, dan pengembangan ilmu pengetahuan.

Kendala yang dihadapi selama kegiatan berlangsung adalah jalan yang dilalui menuju Dusun Kuri Caddi tergolong ekstrim berupa jalan

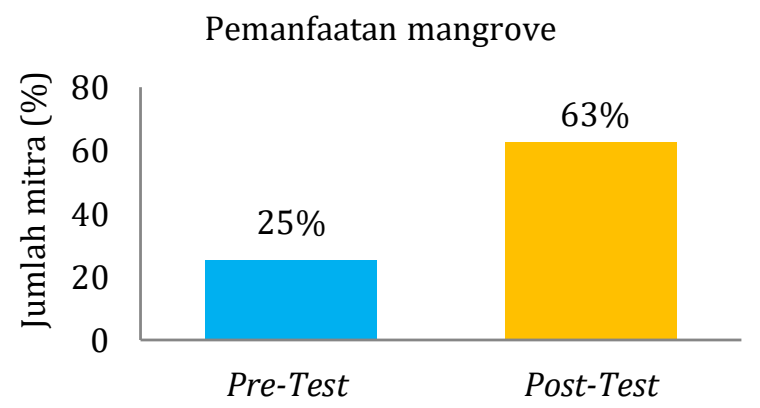

Gambar 3 Hasil pre-test dan post-test kegiatan pemanfaatan mangrove. berbatu dengan banyak lubang serta jembatan yang mulai rapuh. Selain itu, profesi masyarakat sebagai nelayan membuat kami agak sulit menentukan jadwal pengajaran dengan masyarakat. Penunjukan tiga masyarakat sebagai kader merupakan bentuk keberlajutan dari program ini. Ketiga masyarakat kader ini dipilih berdasarkan hasil dari pre-test dan pos-test tertinggi serta keaktifan kader tersebut selama mengikuti kegiatan ini.

\section{SIMPULAN}

Kegiatan PKM-M Blue-Forest yang telah dilaksanakan menunjukkan peningkatan pengetahuan terhadap tiga materi (pengenalan mangrove, bagian-bagian mangrove, dan pemanfaatan mangrove) mengenai mangrove yang mana awalnya pengetahuan rata-rata mitra hanya sebesar 26\%. Setelah kegiatan ini dilaksanakan, pengetahuan mitra meningkat menjadi sebesar 61\%, serta kesadaran masyarakat akan pentingnya keberadaan mangrove pun meningkat. Hal ini menunjukan bahwa metode-metode yang digunakan, yaitu ceramah, diskusi, dan brainstorming yang diterapkan sudah tepat.

\section{UCAPAN TERIMA KASIH}

Ucapan terima kasih disampaikan kepada Kementerian Riset dan Pendidikan Tinggi (Kemenristekdikti) yang telah mendanai seluruh rangkaian kegiatan Program Kreatifitas Mahasiswa (PKM) pengabdian kepada masyarakat Blue Forest. Ucapan terima kasih juga disampaikan kepada Universitas Hasanuddin (UNHAS) yang telah mendukung program Blue Forest dari awal hingga akhir kegiatan. Selain itu, ucapan terima kasih kepada masyarakat Kuri Caddi atas partisipasi dan dukungan sehingga kegiatan ini dapat berlangsung dengan baik.

\section{DAFTAR PUSTAKA}

Djohan TS. 2007. Distribusi Hutan Bakau di Laguna Pantai Selatan Yogyakarta. Jurnal Manusia dan Lingkungan. 14(1): 15-15.

Halidah. 2014. Avicennia marina (Forssk.) Vierh. Jenis Mangrove yang Kaya Manfaat. Info Teknis Eboni. 11(1): 37-44. 
Kartawinata K, Soemodihardjo S. 1977. Tomlinson PB. 1986. The Botany of Mangrove. Komunitas Hayati di Wiiayah Pesisir New York (US): Cambridge University Press. Indonesia. Oseanologi di Indonesia. 8: 19-32. Widiastuti M, Ruata N, Arifin T. 2018.

Kordi MGHK. 2012. Ekosistem Mangrove: Potensi, Fungsi, dan Pengelolaan. Jakarta (ID): Rineka Cipta.

Suryadiputra INN. 2006. Kajian Kondisi Lingkungan Pascatsunami di Beberapa Lokasi Nanggroe Aceh Darussalam NAD. [Skripsi]. Bogor (ID): Institut Pertanian Bogor. Pemahaman dan Partisipasi Masyarakat Dalam Pengelolaan Ekosistem Mangrove di Pesisir Laur Arafura Kabupaten Maroke. Ejournal-balitbang. 13(1): 111-123. https://doi.org/10.15578/jsekp.v13i1.6853. 